\title{
PHOTOAFFINITY LABELING OF PLATELET ACTIVATING FACTOR BINDING SITES IN RABBIT PLATELET MEMBRANES
}

\author{
Lee-Young Chau ${ }^{a *}$, Yeun-Min Tsai ${ }^{\mathrm{b}}$ and Jiin-Ru Cheng ${ }^{\mathrm{a}}$
}

${ }^{a}$ Division of Eicosanoid and Lipid Mediator Research, Institute of Biomedical Sciences, Academia Sinica, Nankang, Taipei, Taiwan, Republic of China

${ }^{b}$ Department of Chemistry, National Taiwan University, Taipei, Taiwan, Republic of China

Received May 3, 1989

SUMMAKY A photoreactive, radioiodinated derivative of platelet activating factor (PAF), 1-O-(4azido-2-hydroxy-3-iodobenzamido) undecyl-2-O-acetyl-sn-glycero-3-phosphocholine ([ $\left.\left.{ }^{125} \mathrm{I}\right] \mathrm{AAGP}\right)$, was synthesized and used as a photoaffinity probe to study the PAF binding sites in rabbit platelet membranes. The nonradioactive analog, IAAGP, induced rabbit platelet aggregation with an $\mathrm{EC}_{50}$ value of $3.2 \pm 1.9 \mathrm{nM}$ as compared to $0.40 \pm 0.25 \mathrm{nM}$ for PAF. Specific binding of $\left[{ }^{125} \mathrm{I}\right.$ ]AAGP to rabbit platelet membranes was saturable with a dissociation constant $\left(K_{d}\right)$ of $2.4 \pm 0.7 \mathrm{nM}$ and a receptor density $\left(\mathrm{B}_{\max }\right)$ of $1.1 \pm 0.2 \mathrm{pmol} / \mathrm{mg}$ protein. Photoaffinity labeling of platelet membranes with [ ${ }^{125}$ I]AAGP revealed several ${ }^{125}$ I-labeled components by sodium dodecyl sulfate-polyacrylamide gel electrophoresis. A protein species with apparent molecular weight of 52,000 was consistently observed and inhibited significantly by unlabeled PAF at nanomolar concentrations. The labeling was specific since the PAF antagonists, SRI-63,675 and L-652,731, at $1 \mathrm{uM}$ also blocked the appearance of this band; whereas lysoPAF was not effective at the same concentration. These results suggest that the binding sites of PAF receptor in rabbit platelets reside in the pulypeptide of $\mathrm{Mr}=52,000$.

( 1989 Acaderic Press, Inc.

INTRODUCTION Platelet activating factor (PAF), produced by a number of inflammatory cells upon chemical or immunological stimulation, is a potent lipid mediator involved in a variety of pathophysiological states, including asthma, acute inflammation, stroke, thrombosis, graft rejection, ovoimplantation and immune disorders $(1,2)$. Based on structure-function analyses, the biological effects of PAF on target cells or tissues were believed to be receptor-mediated (3). High affinity binding sites for PAF were identified on various cells and in membrane preparations of cells and tissues (4-10). Nevertheless, little was known about the molecular nature of the putative PAF receptors. Recently, we reported the successful solubilization of a $\left.{ }^{3} \mathrm{H}\right] \mathrm{PAF}$-receptor complex from rabbit platelet membranes by using the non-ionic detergent digitonin (11). Hydrodynamic characterization of the radioligand-receptor complex revealed that it is a $\mathrm{Mr}=220,000$ macromolecule. The observation that it retained the sensitivity to sodium ion and guanine nucleotide modulation led to the speculation that the regulatory components, such as GTP binding protein, might coexist with the ligand binding subunits within the complex. In order to gain more insights into the molecular feature of the binding subunits of the PAF receptor, we prepared a photoreactive derivative of PAF which was previously synthesized by Bette-Bobillo et al (12) and used it as a photoaffinity probe to identify PAF binding sites in rabbit platelet membranes. In present report, we

* To whom correspondence should be addressed. 
demonstrated that a membrane component with binding characteristics of the PAF receptor was affinity- labeled and may represent the binding subunit(s) of the PAF receptor in rabbit platelets.

\section{MATERIALS AND METHODS}

Materials- Carrier-free $\mathrm{Na}^{125}$ I was from Amersham. Prestained protein markers were from Bethesda Research Laboratories. N-hydroxysuccinimidyl-4-azidosalicylic acid (NHS-ASA) was obtained from Pierce Chemical Co. Unlabeled 1-O-hexadecyl-2-acetyl-sn-glycero-3-phosphochline (PAF) and 1-O-hexadecyl-sn-glycero-3-phosphocholine (lysoPAF), were from Sigma. SRI-63,675, cis-( \pm )-1-[2-[hydroxy[[tetrahydro-2,5-dimethyl-5-[(octadecylamino carbonyl)-oxy]methyl]furan-2-yl]methoxy-phosphinoxy]ethyl]-quino linium hydroxide was a generous gift from Dr. Dean Handley of Sandoz. L-652,731, trans-2,5-bis(3,4,5-trimethoxyphenyl)tetrahydrofuran, was kindly provided by Dr. T.Y. Shen of University of Virginia.

Synthesis of 1-O-(11-phthalimidoundecyl)-2-O-acetyl-sn- glycero-3-phosphocholine (PAGP)PAGP was prepared according to the published procedure (12) by using (+)isopropylideneglycerol as the starting material with modification (13). HPLC analysis of the resulting product with a nucleosil $50-5$ column $(4.6 \mathrm{~mm} \times 25 \mathrm{~cm})$ eluted with a solvent system of acetonitrile/methanol $/ 85 \%$ phosphoric acid $(130 / 5 / 1.5 \mathrm{~V} / \mathrm{V})(14)$ at tlow rate of $1 \mathrm{ml} / \mathrm{min}$ indicated the presence of $5 \%$ of the regioisomer $(\mathrm{Rt}=21 \mathrm{~min})$ as detected by $\mathrm{UV}$ absorption at $280 \mathrm{~nm}$. The desired PAGP $(\mathrm{Rt}=22 \mathrm{~min})$ was freed from its regioisomer by preparative HPLC and was identical to the material synthesized by Betto-Bobillo et al (12) by comparison with the reported ${ }^{1} \mathrm{H}$ NMR spectrum.

Preparation of 1-O-(4-azido-2-hydroxy-3-iodobenzamido)-undecyl-2-acetyl-sn-glyce ro-3phosphocholine (IAAGP)- 1-O-(11-aminoundecyl)-2-acetyl-sn-glycero-3-phosphocholine (AMAGP, Fig.1) and 1-O-(4-azido-2-hydroxy-3-benzamido)undecyl-2-acetyl-sn-glycero-3-

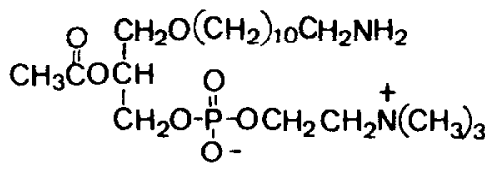

\section{AMAGP}<smiles>CCN(CC)CCOCCOC(=O)ON1C(=O)C2CCC1C2</smiles>

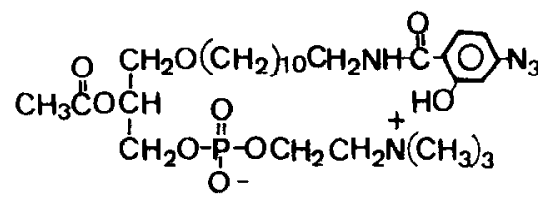

AAGP Chloramine T $\mid{ }^{125} \mathrm{INa}$

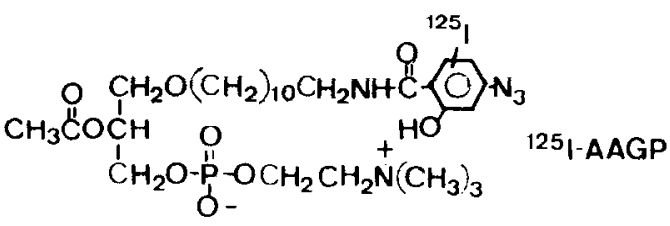

Fig.1. Synthesis of $\left[{ }^{125}\right.$ I]AAGP, a photoreactive analog of PAF. 
phosphocholine (AAGP) were prepared and purified as described (12). AAGP (2.5 mg, $7 \mathrm{umol}$ ) in $0.2 \mathrm{ml}$ of methanol containing $50 \mathrm{ul}$ of concentrated ammonia solution was then treated with iodine ( $2.5 \mathrm{mg}, 10 \mathrm{umol}$ ) which was dissulved in $0.2 \mathrm{ml}$ of $95 \%$ alcohol. After overnight incubation at $4^{\circ} \mathrm{C}$, the reaction mixture was dried under $\mathrm{N}_{2}$ and redissolved in $50 \mathrm{ul}$ of methanol followed by injection onto a HPLC nucleosil $50-5$ column $(4.6 \mathrm{~mm} \times 25 \mathrm{~cm})$. The column was eluted with a solvent system of chlorofom $/ \mathrm{methanol} / \mathrm{H}_{2} \mathrm{O}(65 / 35 / 6)$ at a flow rate of $1 \mathrm{ml} / \mathrm{min}$. As analyzed by $\mathrm{UV}$ absortion at $280 \mathrm{~nm}$, the retention time for the iodinated product and AAGP were $8 \mathrm{~min}$ and $8.5 \mathrm{~min}$ respectively. The fraction at $8 \mathrm{~min}$ was collected in the dark and identified by FAB mass spectrometry as the monoiodinated compound with a molecular weight of $482\left(\mathrm{M}^{1}\right)$.

Preparation of $\left[{ }^{125}\right.$ I]AAGP- Radioindination of AAGP was carried out by the method of Bolton and Hunter (15) with modification. Briefly, $0.25 \mathrm{nmol}$ of AAGP in $5 \mathrm{ul}$ of methanol was mixed with $10 \mathrm{ul}$ of $0.5 \mathrm{M}$ phosphate buffer $\mathrm{pH}$ 7.4. Na ${ }^{125} \mathrm{I}(0.5 \mathrm{uCi}, 5 \mathrm{ul})$ was added followed by $10 \mathrm{ul}$ of chloromine $\mathrm{T}$ ( $50 \mathrm{ug} / \mathrm{ml}$ in $0.5 \mathrm{M}$ phosphate buffer). After standing at room temperature for $2 \mathrm{~min}$, the reaction was terminated by the addition of $10 \mathrm{ul}$ of sodium bisulfate $(30 \mathrm{mg} / \mathrm{ml})$. Five ul of KI $(10 \mathrm{mg} / \mathrm{ml})$ was then added and the iodinated product was extracted into chloroform by mixing $200 \mathrm{ul}$ of methanol, $200 \mathrm{ul}$ of chloroform and $100 \mathrm{ul}$ of $10 \% \mathrm{NaCl}$ and vortexed for $2 \mathrm{~min}$ to affect phase separation. The chloroform layer was removed and washed once more with $10 \% \mathrm{NaCl}$. The isolated ${ }^{125}$ I-product was further purified by HPLC as described above. Over $75 \%$ of radioactivity eluted at $8.0 \mathrm{~min}$ corresponding to the retention time of IAAGP was collected in the dark and stored at $-20^{\circ} \mathrm{C}$ for one month without deterioration. Since the product was completely separated from the starting materials, the specific activity of the radioiodinated compound was assumed to be $2200 \mathrm{Ci} / \mathrm{mmol}$.

Platelet aggregation- Aspirin-treated rabbit platelets were prepared accordingly (16) and finally resuspended in Tyrode's buffer $\mathrm{pH} 7.2$ containing $1 \mathrm{mM} \mathrm{CaCl}$ and the ADP scavenger complex, creatine phosphate $(1 \mathrm{mM})$ and creatine phosphokinase $(10 \mathrm{U} / \mathrm{ml})$ at a concentration of $5 \times 10^{8}$ platelets $/ \mathrm{ml}$. Two hundred ul of platelet suspension were transfered into cuevettes of the aggregameter and stimulated with $10 \mathrm{ul}$ of various concentrations of PAF and PAF analog which were dissolved in $0.15 \mathrm{M} \mathrm{NaCl}$ solution containing $0.25 \%$ fatty acid free bovine serum albumin (BSA). Changes in light transmittance were monitored by a 2-channel NKK Hema Tracer model PAC-2S (NIKO BIOSCIENCE INC. Tokyn, Japan).

Preparation of rabbit platelet membranes- Rabbit platelet membranes were prepared as described previously (11) and finally resuspended in $25 \mathrm{mM}$ Tris-HCl pH 7.4 containing $5 \mathrm{mM}$ EDTA, $0.1 \mathrm{mM}$ PMSF and $1 \mathrm{uM}$ leupeptin with a protein concentration of $10 \mathrm{mg} / \mathrm{ml}$ and stored at $-70^{\circ} \mathrm{C}$ until use. The protein was determined by a Bio-Rad protein assay with BSA as a standard.

Radioligand binding assay- Rabbit platelet membranes were incubated at $4^{\circ} \mathrm{C}$ in $0.5 \mathrm{ml}$ of $25 \mathrm{mM}$ Tris- $\mathrm{HCl} \mathrm{pH} 7.4$ containing $10 \mathrm{mM} \mathrm{MgCl}_{2}$ and $0.1 \mathrm{M} \mathrm{KCl}$ and $0.1 \% \mathrm{BSA}$ and various concentrations of $\left[{ }^{125} \mathrm{I}\right]$ AAGP. After $1 \mathrm{~h}$ of incubation, bound and free ligands were separated by filtration under vacuum on Whatman GF/C glass fiber filters. Each filter was rapidly washed with $10 \mathrm{ml}$ of ice cold buffer and the radioactivity bound to the membrane fraction was determined in a gamma counter.

Photoaffinity labeling - Platelet membrane proteins $(1 \mathrm{mg})$ were incubated with $1 \times 10^{6} \mathrm{cpm}$ of $\left[{ }^{125}\right.$ T]AAGP in $2 \mathrm{ml}$ of binding assay buffer described above in the absence or presence of competing ligand at $4^{\circ} \mathrm{C}$ for $1 \mathrm{~h}$. At the end of incubation, membranes were sedimented at $30,000 \mathrm{xg}$ for $30 \mathrm{~min}$ at $4^{\circ} \mathrm{C}$, resuspended in $1 \mathrm{ml}$ of Tris- $\mathrm{HCl}$ buffer without BSA, and exposed, on ice, to a $254 \mathrm{~nm}$ wavelenght ultraviolet lamp (mineralight R, UVGL-25, 4 watts UVP Inc., San Gabriel, CA) at a distance of $1.0 \mathrm{~cm}$ for $5 \mathrm{~min}$. One $\mathrm{ml}$ of Tris-HCl buffer containig $0.2 \%$ BSA, $2 \mathrm{mM}$ EDTA, $0.2 \mathrm{mM}$ PMSF, $2 \mathrm{uM}$ leupeptin and $2 \mathrm{uM}$ unlabeled PAF was added. After incubation at $4^{\circ} \mathrm{C}$ for $20 \mathrm{~min}$, the membranes were centrifuged at $30,000 \mathrm{xg}$ for $30 \mathrm{~min}$ at $4^{\circ} \mathrm{C}$ and washed once more with Tris- $\mathrm{HCl}$ buffer without BSA followed by centrifugation, again at $30,000 \mathrm{xg}$. The membrane proteins were then solubilized in $0.1 \mathrm{ml}$ of $0.1 \mathrm{M}$ Tris- $\mathrm{HCl} \mathrm{pH} 6.8$ containing $8 \mathrm{M}$ urea, $0.1 \mathrm{M}$ dithiothreitol (DTT) and $3 \%$ SDS at room temperature for $30 \mathrm{~min}$. The samples were analyzed by SDS-gel electrophoresis (SDS-PAGE) on a 10\% acrylamide gel according to the Laemmli method (17). At the end of electrophoresis, gel were dried and exposed to Kodak X-Omat films with intensifying screens at $-70^{\circ} \mathrm{C}$ for two weeks. 


\section{RESULTS AND DISCUSSION}

[ ${ }^{125}$ I]AAGP, synthesized previously by Bette-Bobillo et al (12), was suggested to be a potential probe for photoaffinity labeling of PAF receptor. However, no further data was provided in support of its utility. In attempt to identify the binding sites of the PAF receptor, we synthesized the same compound for further characterization. The nonradioacticve analog was first prepared and its effect on platelet function was examined. As shown in Fig. 2, LAAGP exhibited the agonist activity to induce platelet aggregation with a potency which is one log of magnitude less than that of synthetic PAF. The mean $\mathrm{EC}_{50}$ values for IAAGP and PAF were $3.2 \pm 1.9 \mathrm{nM}$ and $0.4 \pm 0.25 \mathrm{nM}$ respectively for three experiments. When rabbit platelet membranes were incubated with incremental inputs of the radioligand, $\left[{ }^{125} \mathrm{I}\right] \mathrm{AAGP}$, at $4^{\circ} \mathrm{C}$ for an hour, the specific binding of $\left[{ }^{125} \mathrm{I}\right] \mathrm{AAGP}$ to the membranes reach a plateau indicating a saturation at $5 \mathrm{nM}$ (Fig. 3A). Scatchard analysis of the binding data (Fig. 3B) revealed a single high affinity binding site with a dissociation constant $\left(\mathrm{K}_{\mathrm{d}}\right)$ of $3.3 \mathrm{nM}$ and a $B_{\max }$ of $1.2 \mathrm{pmol} / \mathrm{mg}$ protein in the depicted experiment, the mean $\mathrm{K}_{\mathrm{d}}$ and $\mathrm{B}_{\max }$ were $2.4 \pm 0.7 \mathrm{nM}$ and $1.1 \pm 0.2 \mathrm{pmol} / \mathrm{mg}$ protein respectively for three experiments. The binding affinity of the analog was apparently in good correlation to its biological activity on rabbit platelets.

Platelet membranes preincubated with [ ${ }^{125}$ I]AAGP were exposed to UV light followed by solubilization in the presence of DTT, SDS and urea at room temperature for $30 \mathrm{~min}$. Analysis of the
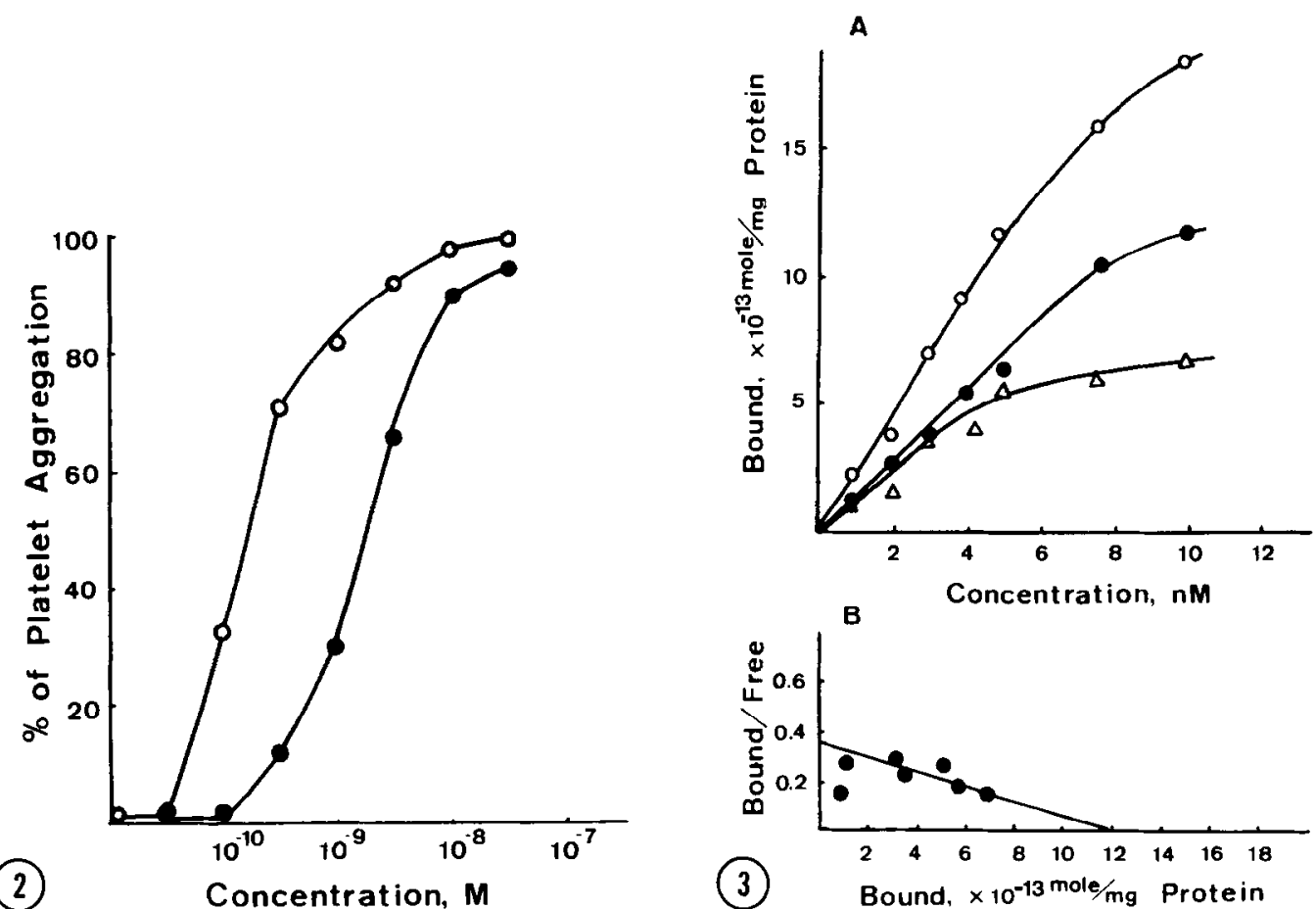

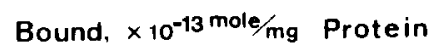

Fig.2. Platelet aggregation induced by various concentrations of PAF $(0)$ or IAAGP $(\bullet)$. The aggregation obtained in response to $10^{-6} \mathrm{MPAF}$ was referred to $100 \%$.

Fig.3. (A) Saturation binding of ${ }^{125}$ I]AAGP to 100 ug of rabbit platelet membranes. The specific activity of [ $\left.{ }^{25} \mathrm{I}\right] A A \mathrm{AGP}$ was adjusted to $50 \mathrm{Ci} / \mathrm{mmol}$ by the addition of unlabeled IAAGP prior to experiments. Each point represents the mean of duplicate determinations for total binding (o), specific binding $(\Delta)$ and non-specific binding $(\bullet)$. (B) Scatchard plot of specific binding of [ ${ }^{125}$ I]AAGP to platelet membranes. 


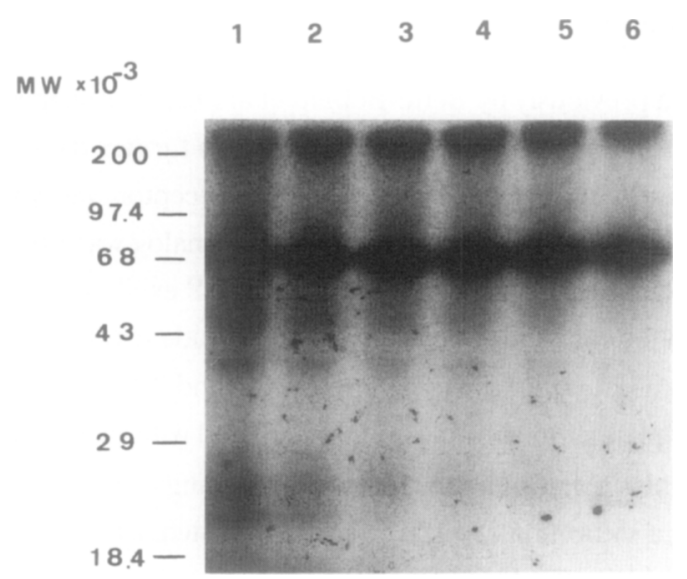

Fig.4. Photoaffinity crosslinking of $\left[{ }^{125} \mathrm{I}\right] \mathrm{AAGP}$ to rabbit platelet membranes. The platelet membranes were incubated with [ $\left.{ }^{125} \mathrm{I}\right] \mathrm{AAGP}$ alone (lane 1 ), and separately in the presence of unlabeled PAF at $10^{-10}$ (lane 2), $10^{-9}$ (lane 3), $10^{-8}$ (lane 4), $10^{-7}$ (lane 5) and $10^{-6}$ (lane 6) $\mathrm{M}$ as described under "Materials and Methods". After irradiation, samples were solubilized and subjected to SDS-PAGE on a $10 \%$ acrylamide gel.

solubilized membranes by SDS-PAGE and autoradiography resolved several ${ }^{125}$ I-labeled components (Fig. 4). The labeling to a protein band at $\mathrm{Mr}=68,000$ was predominant; however it was not protected in the presence of an excess of unlabeled PAF, representative of a non-specific binding protein. Since the $\mathrm{Mr}=68,000$ species happened to have the same molecular weight as BSA, it was very likely the contaminant of BSA which was routinely included in the binding buffer to help the solubility of ${ }^{125}$ I]AAGP in the aqueous solution. However, we speculated that the BSA-like protein is of platelet origin (20) since the photolabeled membranes had been subjected to washing by BSA-free buffer before SDS-PAGE analysis. A diffuse band migrating with an average apparent molecular weight of 52,000 was also visualized and prevented by PAF in a dose-dependent manner with significant inhibition observed at a concentration as low as $10^{-10} \mathrm{M}$. In the depicted experiment, three additional minor species at $\mathrm{Mr}=40,000,24,000$ and 21,000 were also specifically labeled. Although the protease inhibitors, PMSF, EDTA and leupeptin were employed during the preparation of the platelet membranes, it did not exclude the possibility that these smaller molecular weight species were the proteolytic products of the relatively abundant $\mathrm{Mr}=52,000$ species. In fact, the photolabeled membranes were solubilized at room temperature instead of by boiling, which might also increase the chance of proteolysis occurring in SDS/DTT-solubilized polypeptides as reported by others $(22,23)$. Unfortunately, we found that boiling of samples usually resulted in poor appearance of the band in the autoradiograph, indicating that the covalent binding of $\left[{ }^{125}\right.$ I]AAGP to the receptor proteins might be somewhat destabilized by heating. Prolonged exposure to UV light did not seem to improve the situation. The specificity of the labeling to $\mathrm{Mr}=52,000$ was further demonstrated in Fig. 5 . The addition of $1 \mathrm{uM}$ lysoPAF, the inactive deacylated metabolite of PAF, to the incubation mixture, did not influenec the appcarance of the labcled proteins. On the contrary, the specific PAF antagonists,SRI-63,675 (18) and L-651,731 (19), completely blocked the labeling to $\mathrm{Mr}=52,000$ at the same concentration without affecting the $\mathrm{Mr}=68,000$ band. Taken together, these data clearly illustrated that the $\mathrm{Mr}=52,000$ protein displays binding characteristics similar to the PAF receptor and therefore may represent the specific binding component for PAF receptor in rabbit platelets. The observation that the $\mathrm{Mr}=\$ 2,000$ protein migrated as a broad, diffuse band suggests that it is 


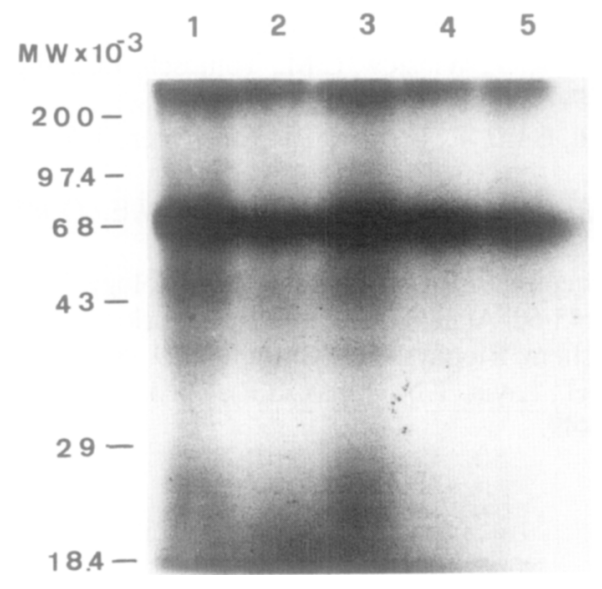

Fig.5. Specificity of the cross-linking of $\left[{ }^{125}\right.$ I]AAGP to rabbit platelet membranes. Platelet membranes were incubated with [ ${ }^{125}$ I]AAGP alone (lane 1), and separately in the presence of $1 \mathrm{uM}$ of unlabeled PAF (lane 2), lysoPAF (lane 3), SRI-63,675 (lane 4) and L-652,731 (lane 5) as described under "Materials and Methods".

glycoprotein which is a characteristic of many membrane receptor proteins (21). Since our previous work demonstrated that under the nondenaturing condition the PAF receptor was solubilized from rabbit platelet membranes as a large complex $(\mathrm{Mr}=220,000)$, it is suggested that the association of the $\mathrm{Mr}=52,000$ polypeptide with other regulatory components is essential for preserving the functional activity of the solubilized PAF-receptor complex.

\section{ACKNOWLEDGMENTS}

This work was supported by Grants NSC-76-0412-B001-03 and NSC-77-0412-B001-01 from the National Science Council of Taiwan.

\section{REFERENCES}

1. Hanahan, D.J. (1986) Ann. Rev. Biochem. 55, 483-509.

2. Braquet, P.,Touqui, L., Shen, T.Y., and Vargaftig, B.B. (1987) Pharmacol. Rev. 39, 97-145.

3. Godfroid, J.J., and Braquet, P. (1986) Trends Phar. Sci. 7, 368-373.

4. Inarrea, P., Gomez-Cambronero, J., Nieto, M., and Sanchez Crespo, M. (1984) Eur. J. Pharmacol. 105, 309-315.

5. Valone, F.H., Coles, E., Reinhold, V.R., and Goetzel, E.J. (1982) J. Immunol. 129, 1637-1641.

6. Valone, F.H., and Goetzel, E.J. (1983) Immunology 48, 141-149.

7. Hwang, S.-B., Lee, C.-S. C., Cheah, M.J., and Shen, T.Y. (1983) Biochemistry 22, 4756-4763.

8. Hwang, S.-B., Lam, M.-H., and Shen, T.Y. (1985) Biochem. Biophys. Res. Commun. 128, 972-979.

9. Domingo, M.T., Spinnewyn, B., Chabrier, P.E., and Braquet, P. (1988) Biochem. Biophys. Res. Commun. 151, 730-736.

10. Stewart, A.G., and Dusting, G.J. (1988) Br. J. Pharmacol. 94, 1225-1233.

11. Chau, L.-Y., and Jii, Y.-J. (1988) Biochim. Biophys. Acta 970, 103-112.

12. Bette-Bobillo, P., Bienvenue, A., Broquet, C., and Maurin, L. (1985) Chem. Phys. Lipids 37, 215-226.

13. Tsai, Y.-M., Jiang, S.-L., Chen, H.-J., Chau, L.-Y., and Lin, J.-T. (1988) J. Chin. Chem. Soc. 35, 429-435.

14. Chen, S.S., and Kou, A.Y. (1982) J. Chromatogr. 227, 25-31.

15. Bolton, A.E., and Hunter, W.M. (1973) Biochem. J. 133, 529-539.

16. Pirotzky, E., Bidault, J., Burtin, C., Gubler, M.C., and Benveniste, J. (1984) Kidney Int. 25, 404-410. 
17. Laemmli, U.K. (1970) Nature (London) 227, 680-685.

18. Handley, D.A., van Valen, R.G., Winslow, C.M., Tomesch, J.C., and Saunders, R.N. (1987) Throm. Haemost. 57, 187-190.

19. Hwang, S.-B., Lam, M.H., Biftu, T., Beattie, T.R., and Shen, T.Y. (1985) J. Biol. Chem. 260,15639-15645.

20. Hitchcock-Degregori, S.E., Gerhard, M.D., and Brown, W.E. (1985) J. Biol. Chem. 260, 3228-3232.

21. Hedo, J.A. (1984) in Receptor Biochemistry and Methodology, Vol.2 (Venter, J.C. and Harrison, L.C., eds) pp. 45-60, Alan R. Liss, Inc. New York.

22. Pringle, J.R. (1970) Biochem. Biophys. Res. Commun. 39, 46-52.

23. Stiles, G.L., Strasser, R.H., Lavin, T.N., Jones, L.R., Caron, M.G., and Lefkowitz, R.J. (1983) J. Biol. Chem. 258, 8443-8449. 